\title{
BASINDA RAUF RAİF DENKTAŞ VE KIBRIS MÜCADELESI
}

\author{
(Rauf Raif Denktaş and the Cyprus Struggle in the Press Summary)
}

Emre GÜLER ${ }^{1}$

Makale Süreci ÖZ

\begin{tabular}{l}
\hline Article History \\
Alındı / Received: \\
04.11.2020 \\
Düzeltme / Revised form: \\
10.12.2020 \\
Kabul edildi / Accepted: \\
18.12.2020
\end{tabular}

Article Type:

Derleme Makalesi

Review Article

\begin{abstract}
Akdeniz'in anahtarı konumundaki Kıbrıs, tarih boyunca savaşların merkezi haline gelmiştir. Uzun yıllar Türk egemenliğinde yaşamış olan adanın Türkiye için önemi ise hem güvenlik açısından hem de orada bulunan Türkler açısından vazgeçilmez niteliktedir. Ada da Yunan sömürgesine karşı, Kıbrıs Türk Halkını esaretten kurtaran ve bağımsızlık mücadelesinde bayrağı en önde taşıyan Rauf Raif Denktaş ve Kıbrıs mücadelesinin mihenk taşlarındandır. Denktaş, kendi çıkarlarını hiçe sayarak ömrünü Kıbrıs davasına adamış, Kıbrıs Türkünün adadaki varlığının devam etmesi ve özgür bir şekilde yaşaması için ömrü boyunca mücadele etmiş̧tir. Çalışmamız, bahsedilen tarihsel süreçte Kıbrıs'ta Türkler, İngilizler ve Rumlar arasında yaşanan mücadelede ve Denktaş'ın hayatı ile bu süreçte yaptıklarını kronolojik bir özetini içermekte ve çeşitli basın yayın belgelerinin değerlendirilmesi, kaynakların taranması aracılığıyla, Kıbrıs konusundaki araştırmalara katkı sağlamak ve geçmişte Kuzey Kıbrıs Türk Cumhuriyeti'nin bağımsızlığı için hayatını kaybedenlerin tekrar hatırlanması amaçlamaktadır.
\end{abstract}

Anahtar Kelimeler: Rauf Raif Denktaş; Kıbrıs; Türkiye Cumhuriyeti; Bağımsızlık.

(C) 2020 BUAAD-BIJAR. Tüm hakları saklıdır.

\section{Summary}

Cyprus, which is the key to the Mediterranean, has been the center of wars throughout history. For many years the importance for Turkey of the island under Turkish sovereignty, who lived there found both in terms of both security is indispensable for the Turks. Rauf Denktaş was one of those who played a vital role in this indispensable Cyprus case.

The first speech of the Turkish Cypriots at the rally organized on 27 November 1948 enabled Denktaş to enter the political life. Faiz Kaymak, who has been the president of the Federation of Turkish Cypriot Institutions since 1950, has held the IV. Upon his withdrawal from the candidacy in favor of Rauf Denktaş at the Ordinary Congress; Denktaş became the president of the Federation of Turkish Cypriot Institutions. After becoming president, Denktash served as a jihadist in the cause of the development of the Turkish Cypriot people and the transport of the Turkish community to an honorable future, of which he has always been proud. This National Case; To prevent the Turkish society from coming under the domination of the Greeks and the unification of the island with Greece at all costs; to ensure our political equality on this part of the homeland. It is the organization of the Turkish Cypriots as soon as possible.

At the beginning of 1950, the terrorist activities of EOKA (Greek Cypriot Terrorist Organization), which aimed to unite the island with Greece, reached its peak. The Turkish Cypriots, declared as enemies against Enosis by EOKA, were forced to live under constant threat. Denktaş, Burhan Nalbantoğlu and Kemal Tanrısevdi founded the Turkish Resistance Organization in 1957, seeing the need for an organization that could withstand the attacks of the EOKA underground organization directed by the Greeks. These organizations have until the day he took the place of the Organization of the volcano and within a short time, Denktash has been turned into an effective Resistance Organization insistent demands by Turkey's experts can respond to EOKA as a result. This organization

\footnotetext{
${ }^{1}$ Sosyal Bilimler Enstitüsü Doktora Öğrencisi, Muğla S1tkı Koçman Üniversitesi, guleremre52@gmail.com.
} 
fought against Greek attacks, especially between 1957-1960 and 1963-1974, in order to ensure the security of the Turkish Cypriots and to destroy the attacks around Enosis.

Resolving the Cyprus issue Rauf in the years 1959-1960 as it enters the process Denktash Cyprus to reach a solution that will protect the rights and interests on the island of Turks people, Turkey Hariciye the Ministry of the work to be done in this regard, has provided significant contributions with their opinions. Denktaş, in the signing of the London Treaty that established the Republic of Cyprus in 1960 and Dr. With F. Küçük, he took part in the London Conference representing the Turkish Cypriot people. Dr. The visits of Küçük and Denktaş to Ankara were effective in the Cyprus problem becoming the national issue of the Motherland during this period. The "arrival of Turkish soldiers on the island", emphasized by Denktaş, came to life thanks to the Zurich and London Treaties (1959), as a result, it played an important role in the arrival of the 650-present Cyprus Turkish Forces Regiment (KTKA) to Cyprus.

The fact that Makarios launched an armed attack against the Turkish Cypriot people within the scope of the Enosis plan and seized the Republic of Cyprus on December 21, 1963, justified Rauf Denktaş's prediction. As a result, the Republic of Cyprus collapsed; The most difficult part of the struggle for freedom and existence of the Turkish Cypriots on the island has begun. In 1964, Denktaş visited İsmet İnönü, the prime minister of the period for the basic needs of the Cypriot people and gave extensive information to the prime minister about what the Greeks did. 1963 Bloody Christmas event in December, she thanks to alert flight that made Cyprus the Turkish government after the named Rum attack "ceasefire" agreement, followed by Turkey, Greece, the United Kingdom and the Government of Cyprus, took The conference decided to held in London. Denktaş, departing from Cyprus on January 7, 1964, came to Ankara to attend the London conference and to head the Turkish Cypriot Delegation.

Denktash, after talks in Turkey in June 1968 began 6 years of talks with the Turkish Cypriot Community on behalf of the 5 July 1970 elections and was elected to the Presidency of the Turkish Communal Chamber. He resigned from this post on 28 February 1973 and was elected the President of the Turkish Cypriot Administration the same day. Denktaş was elected as the President of the Cyprus Turkish Administration Executive Board in 1973, and on February 28, 1973, the Vice President of the Republic of Cyprus, and the President of the Turkish Cypriot Administration.

On July 15, 1974, the National Guard forces under the command of the Greek officers announced that the Greek Republic was declared in Cyprus by making a coup d'etat. Prime Minister Ecevit said, "Nobody should take the opportunity of the chaos in Cyprus and attempt to touch our rights" and did not bow to the warnings of the USA and Britain. By 20 July 1974, the 11-year longing was over and the Turkish Armed Forces started the Turkish Peace Operation in the early hours of the morning in order to ensure peace in Cyprus, to re-establish the constitutional order broken by the Greek coup plotters and to ensure the safety of life and property of the Turkish community based on Article 4 of the international guarantee treaty. started. After the 1974 Turkish Peace Operation, due to the return of Makarios to the island on February 13, 1975, Denktaş reacted to this and suggested establishing a separate state to register that Makarios lost his legitimacy. This proposal of Denktaş was not accepted by the government of that day. As a result, Denktaş made the declaration of the Cyprus Turkish Federated State in 1975. Rauf Raif Denktaş, who rescued the Turkish Cypriot people from captivity and carried the flag in the forefront in the struggle for independence against the Greek colony, and the island became the touchstone of the Cyprus struggle and devoted his life to the Cyprus cause by disregarding his own interests. Our study includes a chronological summary of the struggle between Turks, British and Greeks in Cyprus and the life of Denktaş and what he has done in this period, and to contribute to the researches on Cyprus through the evaluation of various press documents, scanning the sources and It aims to remember those who lost their lives for the independence of the Republic.

Keywords: Rauf Raif Denktaş; Cyprus; Republic of Turkey; Independence. 


\section{GÍRIŞ}

Bugün Akdeniz'deki jeopolitik önemi ve yakın zaman keşfedilen doğal gaz rezervleri ile kaynayan Kıbrıs kazanı tekrar taşmaya başlamıştır. Bunun sonucunda bütün dünyanın gözleri ve elleri tekrar buraya müdahale etmesine sebep olmuştur. Bundan dolayı Kıbrıs'ta mücadele bitmeyecek ve bayrak yarışı şeklinde devam edecektir. En son Ersin Tatar'ın Kuzey Kıbrıs Türk Cumhurbaşkanı seçilmesiyle, yeni hedeflerin gerçekleştirilmesi ve yeni nesillere devredilmesi sağlanacaktır.

Akdeniz'e sahip olmak isteyen her devletin almak istediği Kıbrıs’ta, tarih boyunca Türkler, İngilizler ve Rumlar arasında mücadeleler yaşanmıştır. Uzun yıllar Türk egemenliğinde yaşamış olan adanın Türkiye için önemi ise hem güvenlik açısından hem de orada bulunan Türkler açısından vazgeçilmez niteliktedir. Çalışmamızda, tarihsel süreçte Kıbrıs’ta Türkler, İngilizler ve Rumlar arasında yaşanan mücadeleyi Rauf Denktaş'ın hayatı ile bu süreçte yaptıklarını kronolojik bir özetini içermekte ve çeşitli basın yayın belgelerinin değerlendirilmesi, kaynakların taranması aracılığıyla, Kıbrıs konusundaki araştırmalara katkı sağlamak ve geçmişte Kuzey Kıbrıs Türk Cumhuriyeti’nin bağımsızlığı için hayatını kaybedenlerin tekrar hatırlanması amaçlamaktadır.

\section{Rauf Raif Denktaş}

Milletlerin geçmişinde kurtarıcı kahramanları vardır. Kıbrıs Türklerinin kurtarıcısı olan Rauf Raif Denktaş, kendi çıkarlarını hiçe sayarak ömrünü Kıbrıs davasına adamış, Kıbrıs Türkünün adadaki varlığının devam etmesi ve özgür bir şekilde yaşaması için ömrü boyunca mücadele etmiştir. Denktaş, 27 Ocak 1924 yılında Kıbrıs’ın Baf kazasında doğmuştur (Bozkurt, 28 Şubat 1973,s.1). Denktaş, hâkim Mehmet Rauf R. Denktaş Raif Efendinin dördüncü ve en küçük evladıdır. Mehmet Raif Efendi’nin mesleği adaleti simgelediği için Rauf Raif’e Denktaş soyadı, ağabeyi Cahit tarafından Türkiye'de alınmıştır. Denktaş 18 aylık bebek iken, annesi düşük yaptığ için hastanede hayatını kaybetmiştir (Denktaş, 2000: 41).

Annesi öldükten sonra Denktaş'a 7 yaşına kadar dedesi Şehirli Mehmet Efendi ve anneannesi bakmıştır. Denktaş, 1930 yılında İstanbul Arnavutköy’de ilkokuldan liseye kadar eğitim göreceği Fevzi Ati Ortaokulu'nda yatılı olarak okumaya başlamıştır. Ortaokuldan sonra lise eğitimi için Kıbrıs'a tekrar geri dönmüştür ( Aşkın ve Kılıç, 2003:9).

Lise öğrenimini gördüğü Lefkoşa İngiliz Okulu'nun son sınıfında babasını kaybeden Denktaş, 1941 'de bu okuldan mezun olmuştur. İkinci Dünya Savaşı'nın devam ettiği yıllarda Magosa'da İngiliz Askeri Karargahında İngilizce-Rumca tercümanı olarak görev yapmıştır. Kısa bir süre sonra buradaki işini bırakıp Magosa kaza mahkemesinde kâtip olarak görev yapmıştır. Bir 
zaman sonra buradaki katiplik görevinden ayrılarak, 1943-1944 eğitim-öğretim döneminde İngiliz lisesinde yurt öğretmenliği yapmıştır (Yalçın, 2019:113).

Denktaş Magosa mahkemesinde katipliği sırasında, Kıbrıs Türk halkının liderliğini üstelenen ve aynı zamanda Halkın Sesi gazetesini yayımlayan Dr. Fazıl Küçük ile tanışmıştır. Memur olduğu dönemde Kıbrıs Türklerinin sorunları ile ilgili yazılarını isimsiz olarak yayınlayan Denktaş böylece Kıbrıs Türklerinin geçmişten gelen büyük davasına dahil olmuştur. Bu dava Kıbrıs'ta yaşayan Türk halkının Rum ve Yunan halklarının kölesi olmasını engel olma davasıdır. Bu dava, Yunanistan dışındaki helenlerin bağımsızlığı ve anavatanın Yunanistan ile birleştirilmesi amacı olan Enosis'in başarılı olmasını engellemek, Kıbrıs Türkünün adada varlığını güven içinde devam ettirmesi ve özgürce yaşaması davasıdır (Denktaş, 2000: 228). "Megali idea (Büyük Hedef) olarak da adlandırılan bu amaçlar nedeniyle Kıbrıs’ta 1950’lerde, İngiliz yönetimine karşı RumYunan İkilisinin silahlı bir özgürlük mücadelesinin” başlatılmasına karar vermesi üzerine, Ada'da Yunanistan'ın Kıbrıs'ı ilhak etmek amacıyla kurduğu yasa dışı bir yeraltı örgütü olan EOKA yer altı terör örgütünü kurmuş ve Kıbrıs’ta anarşi ve terör eylemlerini planlayıp yönetmiştir. Bugün yüzlerce İngiliz, Rum ve Türk’ün öldürülmesine sebep olmuştur (Avc1., Doğanay ve Atun, 2016: 91).

Rauf Denktaş, babasının da istediği gibi iyi bir avukat olmak için, İkinci Dünya Savaşı yıllarında hukuk eğitimi almak üzere 1944 yılında İngiltere’ye gitmiştir. Denktaş İngiltere'de burslu olarak hukuk tahsiline başlamıştır. İngiltere'deki hukuk eğitimini 1947 senesinde bitiren Denktaş, Barrister-At-Law unvanını almıştır. Kıbrıs'a dönen Denktaş, adada avukatlık yapmaya başlamıştır (Bozkurt, 26 Haziran 1970:1).

Aydın hanımla evli olan Denktaş'ın üç oğlu ile üç kızı olmuştur. Bir kızını beyin tümörü nedeniyle 2 buçuk yaşında, bir oğlunu 7 yaşında bademcik ameliyatı sırasında kaybetmiştir. Diğer oğlu Raif aynı zamanda Cumhurbaşkanlığı Siyasal İşler Özel Danışmanlığı görevini yürütmektedir. Raif Denktaş, 1985 yılında Gazi Magosa'dan Lefkoşa'ya dönerken geçirdiği trafik kazasında ağır yaralanmış, Ankara'da tedavi altına alındığı hastanede, 34 yaşında vefat etmiştir. Rauf Denktaş’ın oğlu Raif, Lefkoşa'da büyük bir devlet töreni ile toprağa verilmiştir (Cumhuriyet, 29.12.1985:7).

Denktaş, Kıbrıs'a döndüğünde önceden tanıştığı Dr. Fazıl Küçük, tarafindan yayımlanan Halkın Sesi gazetesinde, imzalı ve imzasız bazen de Akın Yılmaz adı altında yazılar yazmaya devam etmiştir. Denktaş yazılarında, küçüklüğünden beri babasından ve onun vatanperver dostlarından işiterek öğrendiği “Türk haklarının İngilizler tarafından gasp edilmesi” problemine ağırlık vermiştir (https://kktcb.org/tr/cumhurbaskanligi/cumhurbaskanlari/rauf-raifenktas.ErișimTarihi:03.04.2020). 
Adaya dönüşünde Türk toplumunu sorunlar içinde bulan Denktaş, 27 Kasım 1948 yılında Kıbrıs Türklerinin düzenlediği ilk mitingde, Dr. Fazıl Küçük ile yaptığı hatiplik sayesinde Kıbrıs Türkleri tarafından tanınmıştır. Genç bir avukat olarak yaptığı bu konuşma ile Kıbrıs mücadelesi başlamıştır. Daha sonra Türk cemaatinin iki önemli ismi Faiz Kaymak ile Dr. Fazıl Küçük arasında arabulucu rolünü üslenip, Türk toplumunun yararına olan her şeyin takipçisi olmuştur (Aşkın ve Kılıç, 2003:9).

Denktaş’ın Türk toplulukları adına ilk resmi görevi, 1948 yılında anayasa komisyonu üyeliği ile başlamıştır. 1947 yılının başında İngiliz hükümeti tarafından atanan Vali Lord Winster, Kıbrıs için yeni bir yönetim şekli hakkında, hükümetle müzakereler yapacak ve tavsiyelerde bulunacak bir anayasa komisyonu kurmuştur. Kurulan bu komisyonun 7 üyesi Türk ve 12 üyesi Rum kesiminden oluşmaktadır. Komisyondan çıkan kararlar, adadaki Türk ve Rum toplumlarının eşitliğini ön plana çıkardığı ve Enosis'e kapalı bir yönetim öngördüğü için Denktaş’ın sekreterliğini yaptığı anayasa komisyonunun çalışmaları başarılı olamamıştır (Gazioğlu, 1996:375386).

1948 yılında kurulan anayasa komisyonu, Rum kilisesinin baskısı altında Konsey’e katılmış olan Komünist Akel Partisi'nin çekilmesi sonucunda kapatılmıştır. Türk temsilcilerin 1srarlı talepleri sonucu Hâkim Mehmet Zekâ Bey'in başkanlığında 11 Haziran 1948'de Türk İşleri Komisyonu kurulmuş, Rauf Denktaş bu komisyonda çalışarak, İngiliz Sömürge İdaresi'nin Türk toplumunun elinden alınan temel hakların iadesi için bir raporun hazırlanmasında hayati önem taşımıştır. ${ }^{3}$ İngiliz yönetiminin teklifi üzerine yasaların yapılması için 1949 yılında kendi kurduğu hukuk bürosunu bırakıp, küçük bir maaş karşılığında önce savcı yardımcılığına atanan Denktaş, ardından 1949-1959 Yılları arasında Kıbrıs’ta savcılık görevini ifa etmiştir.(https://kktcb.org/tr/cumhurbaskanligi/cumhurbașkanları/rauf-raif-denktas.ErişimTarihi:03.04.2020).

Denktaş’a eski hikâyeleri anlatan dedesi Mehmet Efendi, 1878 yılında göklerdeki Türk bayrağının yerine İngiliz bayrağının yükselmesini görmüştür. Dedesi “Osmanlı yamandı..., Gittiler fakat tekrar dönecekler..., ben göremeyeceğim ama sizler şahit olacaksınız” sözleri ile adanın tarihi ile ilgili bilgiler anlatmıştır (Denktaş, 2008:5). İngiltere'nin 1914 yılında başlayan Birinci Dünya Savaşı sebebiyle, Kıbrıs'ı sahiplenmesi haksızlı̆̆a neden olmuştur; 1923 yılında imzalanan Lozan Antlaşması'nda Kıbrıs'ın İngilizlere bırakılması kesinleşmiş ve Yunanlılar da buna razı olmuştur. Bundan dolayı Yunanistan'ın Kıbrıs'ı ilhak etmek istemesine karşı Türkiye'nin aynı hakkı istemesi en doğal hakkıdır. Çünkü 40 mil ötedeki adanın eski sahibi Türkiye'nin, 600 mil mesafedeki Yunanistan'dan daha çok hakkı vardır. Dedesinden ve babasından öğrendiği bu bilgiler sayesinde 
milliyetçi bir lider olarak Denktaş, hayatı boyunca Türkiye’ye sevgi ve sadakat duygusu ile bağlı kalmıştır (Denktaş, 2005:14-15)

"Âlemin bal şerbetinden bana ne?

İşte önümde benim ayran tasım,

Ne malım, mülküm var, ne azı̆̆ım

Olsun diye çalışırım.

Senin başını sokacak bir yerin olsun diye,

Senin bir dikili ağacın!

Amma özgürlüğü kulluğa

Taş çatlasa satmam.” (Denktaş, 2000: 4)

Yukarıdaki Mevlana'nın dizelerini kendine şiar edinen, İlkokul yıllarındayken sürekli Türkiye'ye gidip pilot olma hayalleri kuran Denktaş, “Küçük Tayyareci” şiirini okumayı çok severdi:

“Tayyareci yapacak çocuğunu babalar...

Düşman! Bu küçük tayyareciyi tanı.

Kanatları altında saklayacak vatanı” (Denktaş,2008:18).

Denktaş, başöğretmeni Sarıca'dan her zaman şu sözleri duyardı; "Rumlar bu Türk toprağını Yunanistan'a bağlamak istiyorlarmış, bunu asla başaramayacaklar Çünkü sizler varsınız ... Türkiye vardır." Bu sözleri aklından hiç çıkarmayan Denktaş, Kıbrıs'ı hep kanatlarının altına almak için hayatı boyunca savaşmıştır (Denktaş, 2008:18).

\section{Sosyal yaşamı}

Avukat, siyasetçi ve yazar olan Denktaş, İngilizce ile Rumcayı iyi bilmektedir. Yayımlanmış 50 kitabı ve bir film senaryosu (İşgal Altında adıyla TRT tarafında çekildi) bulunmaktadır. Amerika, İngiltere, Avusturalya, İtalya, Türk Cumhuriyetleri, Polonya, Fransa, Avusturya ve Türkiye Cumhuriyeti'nde fotoğraf sergisi açarak çeşitli ödüler almıştır. Bunun yanında bir dizi konferans vermiştir. İstanbul Üniversitesi İletişim Fakültesi tarafından (1948) Yılın İletişimcisi, Türkiye Gazeteciler Cemiyeti tarafından Yılın Adamı seçilmiştir (Milliyet, 21 Nisan 2000:21). Atatürk Kültür, Dil ve Tarih Yüksek Kurumu tarafından Atatürk Uluslararası Barış Ödülü verilmiştir ( Denktaş, 2007:1). 
Denktaş 07.08.1989 tarihinde Mehmet Ali Birand'ın sunduğu Kıbrıs Belgeseli 'ne konuk olmuştur (Cumhuriyet, 7 Ağustos 1989:9). Rauf Denktaş'a 21 Mayıs 1991 tarihinde Karadeniz Teknik Üniversitesi Senatosunca fahri doktorluk unvanı verilmiştir (Cumhuriyet, 21 Mayıs 1991:10). 1993 yılında İktidardaki Ulusal Birlik Partisini yanlış yol tutmakla suçlayan Denktaş, Kıbrıs Türk Halkını Temsil etme görevinden çekilmiştir (Cumhuriyet, 6 Temmuz 1993:7). Rauf Denktaş’a 19 Aralık 1996 tarihinde İzmir Karşıyaka Belediye Başkanı tarafından verilen “1996 insan hakları ödülünü’ Karşıyaka Nikah Sarayı'nda düzenlenen törende almıştır. Törenin hemen ardından İnsan Hakları Parkına Rauf Denktaş’ın isim plaketi çakılmıştır (Cumhuriyet, 18 Aralık 1996:5). Denktaş 1997 tarihinde hem Mehmet Ali Birandın hazırladığı “32. Gün” programı hem de “Teke Tek” programına katılarak Kıbrıs ile ilgili sorulara cevaplar vermiştir (Cumhuriyet, 13 Ocak 1997:15). Aynı yıl İstanbul Haber Servis tarafından “Dost Gazeteciler 'in Pera Palas Oteli'ndeki aylık yemekli toplantısında 200'e yakın gazeteciye uygulanan anket sonucunda Rauf Denktaş ayın adamı seçilmiştir (Cumhuriyet, 27 Şubat 1997:4). Rauf Denktaş 1997 yılında Zülfü Livaneli’nin sunduğu "Aklın Yolu” programına konuk olmuş ve programda Kıbrıs sorunları ve çözüm yolları hakkında konuşmalar yapmıştır (Cumhuriyet, 27 Şubat 1997:12).

16 Aralık 1999 senesinde Kuzey Kıbrıs Türk Cumhuriyet'inin 16. kuruluş yıl dönümü, Türkiye'deki deprem felaketi sebebiyle sade kutlanmıştır. Denktaş törende, Dış işleri ve Savunma Bakanlığı Dairesi’nin hazırladığı "Direniş Fotoğraflar Sergisini” açmıştır. Aynı yıl Türkiye Lastikİş Sendikası'nın “Gurur Tablomuz 99” ödülünü almıştır (Cumhuriyet, 16 Kasım 1999:10). 2003 yılında Türkiye Barolar Birliği, öldürülen eski Gümüşhane Barosu Başkanı Ali Günday adına düzenlenen "Yılın Hukukçusu” ödülünü KKTC Cumhurbaşkanı Rauf Denktaş’a verilmesini kararlaştırmıştır. TBB Başkanı Özdemir Özok, ödülün yalnızlığa itilmiş Kıbrıs Türk Toplumunun özgür ve insanca yaşama isteğine uluslararası zeminde meşruiyet kazandırmak için 50 yıldır hukuk savaşı veren KKTC Cumhurbaşkanı Rauf Denktaş’a layık olduğunu bildirmiştir (Cumhuriyet, 16 Kasım 1999:10). 2005 yılında KKTC’nin ilk Cumhurbaşkanı Denktaş’a Cumhurbaşkanı Sezer tarafından "Devlet Şeref Madalyası”” verilmiştir. Sezer, Denktaş’1 “Kıbrıs Türklerinin yıllardan beri sürdürdüğü özgürlük, hukuk ve barış savaşının önderi” olarak nitelendirmiştir (Milliyet, 06 Nisan 2005:1).

25 Ekim 2005 tarihinde Kırgızistan-Türkiye Manas Üniversitesi Senatosu tarafindan, Türk Dünyasına yapmış olduğu üstün hizmetlerinden dolayı Fahri Doktora unvanı alan Rauf Denktaş’a, 28 Haziran 2006 - 20. Yüzyıldan İz Bırakan Halk Önderi ödülü verilmiştir. Türkiye tarafından “Türk Silahlı Kuvvetleri Üstün Cesaret ve Feragat Madalyası” verilmiştir (Akar, 2012:13). Denktaş, 24 Aralık 2005 tarihli Kurtlar Vadisi dizisinin 97. Bölümünde kendisini canlandırarak konuk oyuncu olarak yer almıştır (Milliyet, 24 Aralık 2005:11). 


\section{Kitapları}

Rauf Denktaş’ın bugüne kadar yayınlanmış 50'nin üzerinde kitabı, risalesi, yüzlerce makalesi ve bir film senaryosu (İşgal Altında) vardır. Denktaş’ın Kitap çalışmaları aşağıda yer almaktadir:

“Saadet Strları (1941), Ateşsiz Cehennem (1944), Criminal Cases (1953), 12'ye 5 Kala (1965). Akritas Planı (1972), A Short Discourse of Cyprus (1972), The Cyprus Problem (1973), Cyprus Triangle (1981), Gençlerle Başbaşa (1981), Kur'ân'dan Illhamlar (1986), Gençlere Öğ̈̈tler (1988), Imtihan Dünyası, Yarınlar Iç̧in Kıbrıs Girit Olmasın, A Handbook of Criminal Cases, 1955 Cyprus Problem in a Nutshell, 1983 Kadın ve Dünya - Woman and The World, 1985 UN Speeches on Cyprus, 1986 Seçenekler ve Kibris Türkleri - The Options and The Turkish Cypriots, 1986 Cyprus, An Indictment and Defence, 1987 The Cyprus Problem 23rd Year, 1987 My Vision for Cyprus, 1988 Atatürk, Din ve Laiklik - Atatürk, Religion and Laïcité, 1989 Kıbrıs'ta Bitmeyen Kavga - The Unending Fight in Cyprus, 1991 Kibris Davamız - Our Cyprus Issue, 1991 Ilk Altı Ay The First Six Months, 1991 What is the Cyprus Problem, 1991 A Challenge on Cyprus, 1990-91 Denktaş As A Photographer, Images From Northern Cyprus, 1991 The Cyprus Problem and the Remedy, 1992, Nicosia (Lefkoşa) From My Album, 1992 O Günler Those days, 1993, Nicosia Images From Northern Cyprus, 1993 Vizyon - The Vision, 1994, Nicosia Kapllar - Doors, 1995, Nicosia Observations on the Cyprus Dispute, 1996 Kibris Meselesinde Son Durum - The Latest Situation in Cyprus Issue, 1996, Nicosia Rum Yunan Ikilisi: Istenmeyen Cumhuriyetten Nereye? - Cypriot Greek Duo: Where to from the Unwanted Republic, 1996, Nicosia Karkot Deresi - Karkot Creek, 1996 Rauf Denktaş'ın Hatıraları, 1964-74, I. cilt (1964) - Memoirs of Rauf Denktaş, 1964-74, volume I (1964), 1996 Rauf Denktaş'ın Hatıraları, 1964-74, II. cilt (1965), 1997 Rauf Denktaş'ın Hatıraları, 1964-74, III. cilt (1966), 1997 Rauf Denktaş'ın Hatıraları, 1964 74, IV.cilt (1967), 1997 Rauf Denktaş'ın Hatıralart, 1964-74, V. cilt (1968), 1997 Rauf Denktaş'ın Hatıraları, 1964-74, VI. cilt (1969), 1997 Rauf Denktaş'ın Hatıraları, 1964 74, VII. cilt (1970), 1997 Kalbimin Sesi - The voice of my heart, 1997 In Search of Justice, 1997 Rauf Denktaş'ın Hatıraları, 1964-74, VIII. cilt (1971-72), 1998 Rauf Denktaş'ın Hatıralarl, 1964-74, IX. cilt (1973-74), 1999 Hatıralar, Toplayıs, X. cilt Memoirs, Conclusion, vol X, 2000" (Denktaş, 2007: 2). 


\section{Vefatı}

Rauf Raif Denktaş, Kıbrıs Türk halkına, yok olmakla karşı karşıya kaldığı en zor ve en karanlık yıllarda bir ömür liderlik yapan; onlara güç ve cesaret veren ve Kıbrıs denilince ilk akla gelen lider olmuştur. Kıbrıs sorunuyla ilgili 50'nin üzerinde eser vermiştir. Organ yetmezliği teşhisi ile Yakın Doğu Üniversitesi Hastanesi'ne kaldırılan Denktaş, tedavi gördüğü hastanede 13 Ocak 2012 tarihinde 88 yaşında vefat etmiştir.(https://www.timeturk.com/rauf-denktas/biyografi-811815. (Erişim Tarihi:15 Mart 2020).

"Kolay gelmedi bu günler,

Toprağa çelenk oldu şehitler..."

Yukarıdaki mısralar, Rauf Denktaş’ın çok sevdiği Enis Behiç Koryürek'in mısralardır. Bu sefer toprağa çelenk olan mücahit, Kuzey Kıbrıs Türk Cumhuriyeti’nin kurucusu Rauf Raif Denktaş olmuştur (Aşkın ve Kılıç, 2003:175).

Ölüm haberinin alınmasının hemen sonrasında Türkiye ve KKTC'de ulusal yas ilan edilmiştir. Kıbrıs Türk halkı ile Türkiye Türkler’ ini de yasa boğan Denktaş’ın ölümü; T.C. Diyanet İşleri Başkanlığı'nın emriyle Türkiye Cumhuriyeti Devleti’nin sınırları içerisindeki bütün camilerde 13 Ocak 2012'de öğleden sonra sela okunarak bütün Türkiye’ye duyurulmuştur. Aynı gün, yapılan devlet törenine, Türkiye Cumhuriyeti devlet erkanının katılımı ile Denktaş’ın naaş’ı Lefkoşa'daki Cumhuriyet Parkı'nda toprağa verilmiştir (Avcı., Doğanay ve Atun, 2019:233).

Kıbrıs Türklerinin lideri olarak özdeşleşen Denktaş, liderliği boyunca, Kıbrıs Türk halkını İngiliz sömürgesi yönetiminden çıkarıp, üzerinde varlıklarını özgürce ve güvenle devam ettirecek bir vatana, egemen bir devlete kavuşturmuş ve yok olmasını önlemiştir (Avcı., Doğanay ve Atun, 2019:233).

\section{Siyasi Hayatı İle Mücadele Yılları}

Kıbrıs Türklerinin, 27 Kasım 1948 tarihinde organize ettiği ilk mitingde Küçük ile yaptığı ilk konuşması Denktaş'ın siyasi hayata atılmasını sağlamıştır. 1950 yılından beri Kıbrıs Türk Kurumları Federasyon'unun başkanlığını yürüten Faiz Kaymak'ın 27 Ekim 1957'de yapılan IV. Olağan Kongrede Rauf Denktaş lehine adaylıktan çekilmesi üzerine; Denktaş, Kıbrıs Türk Kurumları Federasyon başkanı olmuştur (Cumhuriyet, 29 Ekim 1957:3). Bu görev değişikliği Denktaş'ın Kıbrıs'taki mücadelesini kurumsal boyuta taşıması açısından önemli olmakla birlikte, Dr. Küçük 'ün Türk toplumu içerisindeki liderlik mücadelesini de pekiştirmiştir (Denktaş, 2004:1). Denktaş, başkan olduktan sonra Kıbrıs Türk halkının kalkınmasının ve her zaman gurur duyduğu Türk toplumunun şerefli bir geleceğe ulaştırma davasının bir mücahidi olarak görev yapmıştır. Bu Ulusal Dava; “Türk toplumunun, Rumların tahakkümü altına girmesi ve Ada'nın Yunanistan ile 
birleşmesini, her ne pahasına olursa olsun, önlemek; bu vatan parçası üzerinde siyasi eşitliğimizi sağlamaktır. Kıbrıs Türkeri’nin mümkün olan en kısa zamanda örgütlenmesidir (Özter, 2004: s.49).

1950 yılının başlarında adayı Yunanistan ile birleştirmeyi amaçlayan EOKA ${ }^{4}$ (Kıbrıs Rum Terör Örgütü)'nın terör faaliyetleri zirve yapmıştır. EOKA tarafından Enosis karşıtı düşman ilan edilen Kıbrıslı Türkler, sürekli bir tehdit altında yaşamaya zorlanmıştır. Ulusal davaya sahip çıkan Kıbrıslı Türkler ise EOKA tarafından öldürülmüştür (Denktaş, 1999:s.1).

14 Nisan 1958 tarihli Cumhuriyet Gazetesi haberinde Denktaş; “Kıbrıs’ta Türkler silahlanmak istiyor, canlarını korumaları için İngiliz halkı silahlandırılır da aynı tehlikeye göğüs geren masum Kıbrıs Türkü neden silahlandırılmayıp EOKA’nın insafına terkedilir.?” Şeklindeki bu soru ile EOKA'nın karşısında Kıbrıs Türk halkının nasıl savunmasız kaldığı ve bir an önce silahlanmanın elzem olduğunu anlatmaktadır. (Cumhuriyet, 14 Nisam 1958:1).

Rumların yönlendirdiği EOKA yer altı teşkilatının saldırıları karşısında durabilecek bir kuruluşa ihtiyaç olduğunu gören Denktaş, Burhan Nalbantoğlu ve Kemal Tanrısevdi, 1957'de Türk Mukavemet Teşkilatı'nı kurdu. Bu teşkilat o güne kadar var olan Volkan Teşkilatı'nın yerini aldı ve kısa bir zaman içinde, Denktaş'ın ısrarlı talepleri sonucu olarak Türkiye’nin uzman kişileri tarafından EOKA'ya cevap verebilecek etkin bir Mukavemet Teşkilatı haline getirilmiştir. Bu teşkilat Kıbrıs Türk'ünün her türlü güvenliğini sağlamak, Enosis çevresinde yapılan saldırıları yok etmek için özellikle 1957-1960 ve 1963-1974 yılları arasında, Rum saldırılarına karşı mücadele etmiştir (İsmail, 1998:30). 14 Nisan 1958 tarihli gazete haberinde; “13 Nisan 1958'de Magosa'da İngiliz askeri tarafından kamyonla Türk polisi ezilerek öldürülmüştür. Bu olay üzerine Doktor Fazıl Küçük 'ün, “artık sabrımız tükendi” açıklamasından Türkler ile Rumlar arasındaki sorunların hangi boyuta taşındığı gazetelere yansımıştır (Cumhuriyet, 14 Nisan 1958:1).

Kıbrıs sorununun çözüm sürecine girdiği 1959-1960 yıllarında Rauf Denktaş, Kıbrıs Türk halkının ada üzerindeki hak ve menfaatlerini koruyacak bir çözüme varılmasında, Türkiye Hariciye Bakanlığı'nın bu konuda yapmış olduğu çalışmalara, görüşleri ile önemli ölçüde katkı sağlamıştır. Denktaş, 1960 yılında Kıbrıs Cumhuriyeti'nin kurulmasını sağlayan Londra Antlaşması'nın imzalanmasında ve Dr. F. Küçük ile Kıbrıs Türk Halkını temsilen Londra Konferansı'nda görev almıştır. Dr. Küçük ve Denktaş’ın Ankara'ya yaptığı ziyaretler, bu dönemde Kıbrıs sorununun Anavatanın milli meselesi haline gelmesinde etkili olmuştur. Denktaş’ın üzerinde durduğu "Türk askerinin adaya çıkması", Zürih ve Londra Antlaşmaları (1959) sayesinde hayata geçmiş, bunun sonucu olarak 650 mevcutlu Kıbrıs Türk Kuvvetleri Alayı'nın (KTKA) Kıbrıs'a gelmesinde önemli rol oynamıştır (Erol, 2014: 60). 
Dedesinin "Türk askeri bu adadan gitti, ama bir gün mutlaka geri gelecektir. Belki biz göremeyeceğiz, fakat siz göreceksiniz” sözlerini hiç unutmayan Rauf Denktaş, KTKA’nın adaya gelmesinden sonra, "Evlatlarım beni Türk askerinin tekrar Kıbrıs'a ayak basmasını sağlayan adam olarak hatırlasınlar, başka rahmet istemem.” demiştir. Rauf Denktaş’ın 16 Ağustos 1960 tarihinde Kıbrıs Cumhuriyeti'nin ilanından sonra Kıbrıs Cumhuriyeti Anayasası'nın hazırlanmasında büyük emeği olmuştur. Rauf Denktaş, 1960’ta yeni kurulan ortaklık Cumhuriyeti'nde Cemaat Meclisi Başkanlığına ve İcra Komitesi Başkanlığına seçilmiştir (Avcı, Doğanay ve Atun, 2016:230).

Kıbrıslı Rumlar, Kıbrıs Cumhuriyeti'nin kuruluşundan itibaren Enosis çalışmalarına tekrar başlamıştır. Cumhurbaşkanı seçildikten sonra Makarios bir konuşmasında; Rumlar antlaşmaların olumlu taraflarından faydalanacak, olumsuz taraflarını hükümsüz sayacaklardır demiştir (Gazioğlu, 2002: 546). Denktaş, Makarios’un bu sözlerine karşılık 11 Ağustos 1963 tarihli Cumhuriyet Gazetesi haberinde; Kıbrıs Türklerinin lideri olarak "Bir azınlık olarak Rumlar tarafından idare edilmeyi asla kabul edilmeyeceğini”, Kıbrıs Türklerinin Kıbrıslı Rumlarla eşit haklara sahip olarak yaşamak istediklerini söylemiştir. Denktaş, Makarios’un planlarına ne pahasına olursa olsun karşı koyacaklarını ve haklarını korumak için ölmeye hazır olduklarını söylemiştir (Cumhuriyet, 11 Ağustos 1963:1). Bu olayların ardında iki toplum arasında çatışmalar görülmüştür. 26 Aralık 1963 tarihli Cumhuriyet Gazetesi haberinde; Rum liderlerinin yönlendirmeleri sonucunda Rum polis ve çeteleri masum Türk halkını; çocuk, kadın, genç ve yaşlı ayırmaksızın imha etmek için amansız bir saldırı başlatmıştır. Bu katliam sonucunda Lefkoşa'da merkezde ve köylerde 50'den fazla Türk'ün öldürüldüğü haberi alınmıştır (Cumhuriyet, 26 Aralık 1963:1). Yapılan bu terör faaliyetleri sonucunda, iki toplum arasındaki çatışmalar, adanın her tarafına yayılmasına sebep olmuştur.

Makarios’un 21 Aralık 1963 yılında, Kıbrıs Türk halkına karşı Enosis planı dahilinde silahlı saldırıya geçmesi ve Kıbrıs Cumhuriyeti'ni ele geçirmesi Rauf Denktaş’ın öngörüsünü haklı çıkarmıştır. Bunun sonucunda Kıbrıs Cumhuriyeti yıkılmış; adada Kıbrıs Türklerinin hürriyeti ve var olma savaşının en zorlu kısmı başlamıştır. (Avcı, Doğanay ve Atun, 2016:231). Adadaki genel durum; Türk bölgelerine sığınan göçmenlerimiz ne yiyecek ne de giyecek bulamaz olmuştur. Rum tarafının hükümeti, Türk memurlarına aylık vermeyi kesti ve Rum tüccarlar da Türklere gıda vermeyi kesmiştir. Temel besinler: Un, Kuru fasulye, Şeker, Nohut, Bulgur, Margarin Mercimek, Benzin ve mazot vb. ihtiyaçların yetersiz olduğu anlaşılmaktadır (Denktaş, 1996: 8-9). Türk Cemaat Meclisi Başkanı Denktaş, bu zorlu koşullardan dolayı Türkiye'den yardım istemiş ve istenen yardımlar Türkiye Cumhuriyeti tarafından karşılanmıştır.

EOKA'nın işlediği cinayetlerden dolayı adadaki Türker'in ne can ne de mal güvenliği kalmamıştır. 26 Aralık 1963 tarihli Akın Gazetesi’nde yer alan “Günlerden beri sabırsızlıkla beklenmekte olan Türk müdahalesi dün başladı” haberinde Başbakan İnönü, Garanti Anlaşmasına dayanarak Kıbrıs'a müdahale ettiğimizi ve Kıbrıs’taki alayımızın akşam Lefkoşa'nın Türk 
kesimine ulaştığını bildirmiştir. Türk jetlerinin hava müdahalesi sayesinde Türkiye, Yunanistan ve İngiltere, Kıbrıs’taki birliklerinin müşterek hareketleri hususunda anlaşarak adada ateşkes ilan edilmesine karar vermiştir (Akın, 26 Aralık 1963:1).

1963 olaylarından sonra İnönü ile Denktaş’ın ilk karşılaşmasında İnönü Kıbrıs Meselesi ile ilgili Denktaş'a: “Kıbrıs davası büyük bir maratondur. Nefesini tutan, sabreden kazanacaktır. Ben Kıbrıs meselesini uluslararası bir mesele haline getirerek halledeceğim. Bu da zaman ister, sabır ister" ifadelerine yer vermiştir. Bu zorlu savaşı Dr. Küçük, Denktaş, Kıbrıs Türkleri ve Türkiye Cumhuriyeti el ele vererek Kıbrıs Türkler' ini aydınlığa çıkararak kazanmışlardır (Denktaş, 2005:14-15).

1964 yılında Kıbrıs halkının temel ihtiyaçları için dönemin başbakanı İsmet İnönü’yü ziyaret eden Denktaş, görüşmede başbakana Rumların yaptıkları ile ilgili geniş bilgiler vermiştir. İnönü; Kıbrıs Türk'ünün Rumların insafına bırakılmayacağını, gerekli bütün yardımların derhal yapılacağı, şeklindeki ifadeleri dikkat çekmektedir (Denktaş, 2005:38-39). Başbakan İnönü’nün açıklamalarında Türkiye'nin en kötü şartlarda dahi Kıbrıs Türklerinin yanında olacağı anlaşılmaktadır.

Kıbrıs'ta cumhuriyetin getirdiği anayasal eşitlik uygulamada hayat bulamamıştır. Denktaş’ın 15 Kasım 1967 tarihli Hürriyet Gazetesi haberinde: “1963 Aralık ayında Kanlı Noel Olayları, diye adlandırılan Rum saldırılarından sonra Türk Hükümetinin Kıbrıs'a yaptığı uyarı uçuşu sayesinde “Ateşkes" anlaşmasının ardından Türkiye, Yunanistan, İngiltere ve Kıbrıs Hükümeti, Londra'da düzenlenen Konferansa katılım kararı almışlardır. 7 Ocak 1964 tarihinde Kıbrıs’tan yola çıkan Denktaş, Londra konferansına katılmak ve Kıbrıs Türk Heyetine başkanlık etmek üzere Ankara’ya gelmiştir” (Hürriyet, 15 Kasım 1967:1). Denktaş’ın BBC muhabirine verdiği demeçte; Canlarını vererek, Türk Cemaatinin, canını, malını ve şerefini koruyanlara ihanet etmeyeceğiz şeklindeki ifadeleriyle Londra Konferansı'nda Kıbrıs Türklerini yeniden Rumların merhametine bırakmayacağını ve en iyi şekilde temsil edeceğini anlaşılmaktadır (Bozkurt, 8 Ocak 1964:1).

Rauf Denktaş'ın Kıbrıs'taki Rumlar tarafından yapılan zulümlerle ilgili 8 Ocak 1964 tarihli Milliyet Gazetesi'ndeki haberde; Zürih ve Londra antlaşması ilk günden beri gereği gibi uygulanmamış ve her zaman Türklerin aleyhine bozulmuştur. Buna rağmen garantör devletlerin hiç birisi, Yunanistan bir tarafa ne İngiltere ne de Türkiye enerjik bir müdahalede bulunmamıştır. Böylece meydanı boş bulan Makarios ve Kıbrıs EOKA'cıları bu defa, hiçbir zaman tam olarak uygulamadıkları, anayasanın tadilini isteyecek kadar ileri gitmiştir. Makarios'un bu hareketleri daha ilk günden garantör devletler tarafından enerjik müdahalelerle durdurulmuş olsaydı, bugünkü fecaati önlemek mümkün olabilirdi. Bunu yapamadıklarından her üç devlet de bugün adadaki can kaybından insanlık önünde sorumlu olacaklardır (Milliyet, 8 Ocak 1964:1). 
Denktaş, 17 Şubat 1964 tarihli hatırasında Kıbrıs’taki durumu şöyle ifade etmiştir; New York’a 15 Ocak 1964 Londra Konferansı bir netice vermedi. Daha da artan Rum saldırılarına karşı adaya Barış Gücü gönderilmemiştir. Makarios resmen oyun oynuyor; görüşmeleri sürekli uzatıp, Kıbrıs Türklerini adadan top yekûn imha etmek için terör gücü hazırlıklarını tamamlamak için elinden geleni yapıyor. 23 Aralık’tan bu yana tam 66 gün geçmiş...Rum saldırıları daha da artarak devam etmesine rağmen adaya halen Barış Gücü gönderilmemiştir (Denktaş, 1996:115).

Denktaş'ın 1964 yılındaki Londra Konferansı'ndan sonra adaya dönmek üzere olduğu duyulunca Makarios tarafından "İstenmeyen Adam” ilan edilmiştir. Bunun sonucu olarak Denktaş'ın Kıbrıs'a girmesi yasaklanmıştır (Bozkurt, 26 Haziran 1970:1). 1964 yılındaki bu olay Denktaş'ın Kıbrıs'tan 4 yıl 4 ay uzak kalmasına sebep olmuştur.

Denktaş’ın hatırasındaki 1965 yılının ilk günü Kıbrıs’ta Türk halkının üzerinde kara bulutlar dolaşıyor; ölüm, esaret, yokluk, açlık, vahşet, katliam... Ve yediden yetmişe, Kıbrıs Türkü’nün özgürlük mücadelesi, var olabilme kavgası ve direnişi devam ediyor, şeklindeki ifadelerinden de anlaşıldı̆̆ı üzere Türkiye'de Kıbrıs davasından başka bir işle uğraşmayan, aklından Kıbrıs Türklerini çıkarmayan ve onların ne zorluklar çektiğini en iyi bilenlerden biri olduğu anlaşılmaktadır (Denktaş, 1997:1).

Denktaş'ın Türkiye'de yaşadığı yıllarda Rumların, Magosa'da Türk evlerine elektrik vermediği (Akın, 19 Eylül 1968:1) ve Rum bölgelerindeki Türk mallarına el koydukları haberleri yer almıştır. Rumların bu yaptıklarının sebebi olarak Türkler 'in devlete karşı isyan ederek, Rumlara saldırdıklarını ve kendilerine büyük zararlar verdiklerini iddia etmişlerdir. Rumlar bu iddiaya dayanarak Türkler'in elektriklerini kesmeye ve Türk mallarına el koymaya kalkıştıkları anlaşılmaktadır (Akın, 14 Mart 1967:1).

Kıbrıs'a Türk toplumunun birlik halinde mücadele etmesini sağlamak için gizli giriş yaparken Rum polisleri tarafından yakalanan Rauf Denktaş ile arkadaşları Erol İbrahim ve Nejat Konuk tutuklanmıştır. Türk Hükümetinin Yunanistan’a verdiği sert notadan sonra Rum yönetimi tarafından serbest bırakılan Denktaş ve arkadaşları 13 Kasım 1967'de Lefkoşa'dan Türkiye'ye dönmüşlerdir (Bozkurt, 14 Kasım 1967:1). Denktaş, Ankara’ya dönüşünde yapmış olduğu açıklamada; “çocuklarıma, aileme kavuştuğum için çok mutluyum. Fakat Kıbrıs Türkleri’ne kavuşamadığım için hiç şüphesiz çok üzgünüm. Belki bu hadise adaya normal yollardan dönüşümü sağlar" şeklindeki ifadelerinde Kıbrıs Türklerinin yanında ne kadar çok olmak istediğini dile getirmektedir (Bozkurt, 13 Kasim 1967:1).

Denktaş, Türkiye'de geçirdiği zorlu yılları şu benzetmeyle ifade etmiştir. Namık Kemal sürgündeyken, Kıbrıs’ta yaşamaktadır ve çektiği sıkıntıları bir kitabında kızına yazdı̆̆ı bir mektupla şu şekilde ifade etmiştir; "Vatan hasretine mi, evlat hasretine mi yanayım? Bunlara da dayanmak mümkün de Kıbrıslıların dedikodularına dayanmak hiç de mümkün değil” Namık 
Kemal'in bu kitabından etkilenen Denktaş, yaşadıkları benzer olayı şu şekilde ifade etmiştir; Galiba küçük yerlerin kaderi bu! Ben de Türkiye'de kalmak zorunda olduğum 4 yıl 4 ay sürecinde Kıbrıs'ta arkamdan yazılanlara ve sözlü olarak yayılan dedikodulara dayanmak, sabretmek, kahrolduğum halde Allah'a sığınarak yoluma devam etmek zorunda kaldım (Denktaş, 2005: 48).

Rauf Denktaş, 13 Nisan 1968 tarihinde adaya giriş yasağı kaldırılınca Kıbrıs'a dönmüştür. Adaya dönüşünde muazzam bir törenle karşılanan Denktaş’ı karşılayanların başında Dr. Fazıl Küçük yer almıştır. Karşılamanın ardından yapılan devlet korteji ile Denktaş tarafından Atatürk Heykeli'ne, Mücahitler Şehitliği'ne çelenk bırakılmış ve daha sonra hatıra defterini imzalamıştır (Akın, 13 Nisan 1968:1).

Denktaş, 1968 yılının haziran ayında Türk Toplumu adına Rumlarla 6 yıl sürecek görüşmelere başlamış ve 5 Temmuz 1970 seçimlerinde Türk Cemaat Meclisi Başkanlığı'na seçilmiştir (Bozkurt, 7 Temmuz 1970:1). Bu görevinden 28 Şubat 1973 tarihinde istifa etmiş ve aynı gün Kıbrıs Türk Yönetimi Başkanı seçilmiştir. 1973 yılında Kıbrıs Türk Yönetimi Yürütme Kurulu Başkanlığına seçilen Denktaş, 28 Şubat 1973’te Kıbrıs Cumhuriyeti Cumhurbaşkanı Muavini ve Kıbrıs Türk Yönetim başkanı olmuştur (Cumhuriyet, 24 Nisan 1990:3).

15 Temmuz 1974 tarihinde Yunanistan'a bağlı subayların yönetimindeki Ulusal Muhafız Gücü kuvvetleri bir hükümet darbesi yaparak Kıbrıs'ta Yunan Cumhuriyeti ilan edildiğini açıklamıştır. Başbakan Ecevit "kimse Kıbrıs’taki kaosu fırsat bilip haklarımıza dokunmaya kalkışmasın” demiştir ve ABD ve İngiltere'nin ikazlarına boyun eğmemiştir. 20 Temmuz 1974 yılına gelindiğinde 11 yıllık hasret bitmiş ve Türk Silahlı Kuvvetleri uluslararası garanti antlaşmasının 4. Maddesine dayanarak Kıbrıs’ta barışı sağlamak, Rum darbecilerin bozduğu anayasal düzeni yeniden kurmak ve Türk toplumunun can ve mal güvenliğini sağlamak için Türk Barış Harekâtı'na sabahın erken saatlerinde başlamıştır (Cumhuriyet, 21 Temmuz 1974:1).

Başbakan Ecevit'in Kıbrıs Barış Harekatıyla ilgili “Kıbrıs Türkü’nün özgürlüğe kavuşmasının Türk milletini mutlu kıldığını belirtmiştir. Bir asırlık hasretin bittiğini ve Kıbrıs Türkü bir daha karanlık günlere dönmemek üzere aydınlığa kavuştu” şeklindeki açıklamaları Kıbrıs Türklerinin ne kadar zor durum'da oldukları göstermiştir. Başbakan Ecevit, “Kıbrıs Barış Harekatı'nda 57 şehit verdiğimizi, 242 askerimizin kayıp olduğu ve 600 esir Rum askerinin Mersin'e getirildiğini”' ifade etmiştir. Büyük devletlerin Türkiye’ye karşı yaptırımlarına rağmen zor şartlarda gerçekleştirilen Kıbrıs Barış Harekat'ı sayesinde adada yaşayan Rumlar'ın Kıbrıs Türkleri üzerindeki, can ve mal güvenliği ve temel haklar konusundaki ihlalleri son bulmuştur (Cumhuriyet, 24 Temmuz 1974:1).

1974 Türk Barış Harekâtı sonrasında 13 Şubat 1975'te Makarios’un adaya dönüşü nedeniyle, Denktaş buna reaksiyon göstererek Makarios'un meşruiyetini kaybettiğini tescil için ayrı devlet kurmayı önermiştir. Denktaş’ın bu önerisi o günkü hükümet tarafından kabul edilmemiştir. 
Bunun sonucunda Denktaş, 1975 yılında Kıbrıs Türk Federe Devleti'nin ilânını sağlamıştır. Yeni kurulan Kıbrıs Türk Federe Devleti’nin Başkanlığı ve Meclis Başkanlığı görevlerine getirilmiştir (Cumhuriyet, 1 Ocak 1975:10).

Başbakan Sadi Irmak’ın 1975 yılında Güneş Gazetesi’ne verdiği; “Dünya’da İkinci Türk Cumhuriyeti olan, Kıbrıs Türk Cumhuriyeti ilan edilmiştir” başlıklı demeçte; Kıbrıs Federal Türk Cumhuriyeti'nin kurulduğunu ve Cumhuriyet'in ilan gerekçesinin 1960 Anayasası'nın Türklere tanıdığı hakların tekrar kazanılmasını sağlamak olduğunu açıklamıştır (Güneş, 13 Şubat 1975:1). Kıbrıs Türkleri Federe Devlet Anayasası uyarınca 20 Haziran 1976 günü yapılan ilk genel seçimlerde büyük bir çoğunlukla, Ulusal Birlik Partisinin adayı Rauf Denktaş halk tarafından devlet başkanlığına seçilmiştir (Cumhuriyet, 22 Haziran 1976:1). Rauf Denktaş bir hatırasında; 1940 yılının başında Kahire'deki bir falcının bana altı evladımın olacağını, hayatta başarı sağlayacağımı fakat zengin olamayacağımı, çok sıkıntılı günleri sabırla atlatacağımı ve bir halkın başında devlet kuracağımı söylemişti... Devlet kurma kehanetine çok gülmüş, hiç önemsememiştim (Denktaş, 2005:68). Kahire'deki falcının söyledikleri 35 yıl sonra gerçek olmuş, Denktaş Kıbrıs Türk Cumhuriyeti'nin kurucusu olmuştur.

Denktaş, 1981 yılında ikinci kez devlet başkanlığına seçilmiştir. 1983 'te Kuzey Kıbrıs Türk Cumhuriyeti'ni ilan edilmiş ve 9 Haziran 1985 'te KKTC'nin ilk cumhurbaşkanlığına seçilmiştir (Cumhuriyet, 25 Eylül 1988:9). Denktaş cumhurbaşkanı seçilmesinin ardından ilk resmi gezisini Ankara'ya Kenan Evren'in konuğu olarak 12 Haziran 1984 gerçekleştirmiştir. Görüşmede Kıbrıs ile ilgili son gelişmelerin değerlendirilmesi yapılmıştır (Cumhuriyet, 5 Haziran 1984:1).

İki devlet arasındaki bağ en güzel 20 Temmuz 1984 tarihli Cumhuriyet Gazetesi'ndeki; "Bebek sağlıklı büyümektedir" haberinde görülmektedir. Haberde; KKTC Cumhurbaşkanı Rauf Denktaş, 15 Kasım 1983‘te ilan edilen Kuzey Kıbrıs Türk Cumhuriyeti'nin bağımsızlığı için yapılan Barış Harekatının 10. yılında ulaştığı yeri değerlendirmiştir. Bağımsızlık ilanı sırasında Denktaş, "Bebek doğmuştur, artık ana rahmine geri dönmez” sözünü 8 ay sonra yorumlarken "Bazı ekonomik sorunlar olmasına rağmen bebek sağlıklı büyümektedir” demiştir (Cumhuriyet, 20 Temmuz 1984:1). Aynı yıl Türkiye Cumhuriyet'i KKTC'yi tanıyarak ilişkilerini büyükelçilik düzeyine çıkarmıştır. Ankara'daki KKTC Temsilciliği büyükelçilik statüsüne getirilmiştir ve Peker Turgut, Ankara'da Kenan Evren'e, İnal Batu Lefkoşa'da Rauf Denktaş’a güven mektupları vermiştir (Cumhuriyet, 18 Nisan 1984:1).

Denktaş 1984 yılının ocak ayında 43 yıllık mücadele arkadaşı Dr. Fazıl Küçük'ü kaybetmiştir. Denktaş, tören alanında toplanan büyük kalabalığa hitaben bir konuşma yapmıştır. Konuşmasında: "Seni kalplerimize gömüyoruz." demiştir. Bu sözden sonra cenaze, Yasama Meclis binasından alınıp toprağa verilene kadar 5 dakika boyunca top atışı yapılmıştır (Cumhuriyet, 24 Ocak 1984:11). 
İki y1l sonra Rauf Denktaş 12 Mayıs 1986 yılında, Londra'da suikasta uğradığı haberin doğru olduğunu kabul etmiştir (Cumhuriyet, 13 Mayıs 1986:1). Londra'da, Cenevre'de, Kahire'de, New York Birleşmiş Milletler 'de ve daha birçok ülkede Kıbrıs Türklerinin haklarını savunan Rauf Denktaş, 22 Nisan 1990 tarihinde yapılan erken seçimde, Kıbrıs Türk’ünün 30 yıllık lideri olarak yeniden cumhurbaşkanı seçilmiştir. Yapılan cumhurbaşkanlığı seçiminde Rauf Denktaş, oyların \%66,72'sini almıştır (Cumhuriyet, 23 Nisan 1990:1). Kuzey Kıbrıs Türk Cumhuriyeti’nde, 22 Nisan 1995 yılında yapılan cumhurbaşkanlığı 2. tur seçimlerini bağımsız aday olan Rauf Denktaş kazanmıştır. Denktaş yapılan seçimde \%63 oy alarak rakibi Derviş Eroğlu'nu geride bırakmıştır (Milliyet, 28 Nisan 1995:19).

Rauf Denktaş, 2000 yılındaki seçimlerde \%43,67 oranında oy almasına rağmen seçim ikinci tura kalmıştır. Fakat ikinci tura kalan diğer aday Derviş Eroğlu'nun çekilmesi üzerine seçimleri kazanmıştır. Denktaş, 2004 yılında BM genel sekreteri Kofi Annan'ın Kıbrıs Sorununun çözümü için hazırladığı Annan Planı'na karşı çıkmıştır. Annan Planı için yapılan referandumda Kıbrıslı Türkler 'in \%65 evet oyuyla kabul edilse de Rumlar \%75'i aşan hayır oylarıyla plan hayata geçmemiştir (Cumhuriyet, 25 Nisan 2004:1). 17 Nisan 2005 tarihinde, Rauf Denktaş'ın katılmadığ cumhurbaşkanlığı seçimlerinde oyların \%56’sını alan Başbakan Mehmet Ali Talat cumhurbaşkanı seçilmiştir. Talat, Denktaş'a “marjinal bir duruş” sergilememesi halinde kendisiyle çalışmaya hazır olduğunu bildirmiştir. 20 Nisan 2005 günü resmen görevini devredecek olan Rauf Denktaş, "Yeminine sadık kalan lideri ölesiye destekleriz, aksi halde karşısında dikiliriz” sözleriyle görevi devretmiştir (Cumhuriyet, 18 Nisan 2005:1).

\section{Sonuç}

Uzun yıllar Rumlar, Yunanlılar, İngilizler ve Türkler arasında sorun teşkil etmiş olan Kıbrıs, yapılan mücadeleler sonucunda kuzey ve güney olmak üzere iki devlet halini almıştır. Uzun yıllar Türk egemenliğinde yaşamış olan adanın günümüzde Türkiye için önemi ise hem güvenlik açısından hem de orada bulunan Türkler açısından vazgeçilmez niteliktedir. Ada da Yunan sömürgesine karşı, Kıbrıs Türk Halkını esaretten kurtaran ve bağımsızlık mücadelesinde bayrağı en önde taşıyan Rauf Raif Denktaş ve Kıbrıs mücadelesinin mihenk taşlarındandır. Denktaş, kendi çıkarlarını hiçe sayarak ömrünü Kıbrıs davasına adamış, Kıbrıs Türkünün adadaki varlığının devam etmesi ve özgür bir şekilde yaşaması için ömrü boyunca mücadele etmiştir. Kıbrıs Türk halkına, yok olmakla karşı karşıya kaldığı en zor ve en karanlık yıllarda bir ömür liderlik yapan Denktaş; onlara güç ve cesaret veren ve Kıbrıs denilince ilk akla gelen lider olmuştur. 


\section{KAYNAKÇA}

Aşkın, R. ve Kılıç, M. (2003). Mehmet, Kıbrıs Girit Olmasın. Ankara: Remzi Kitapevi.

Avcı, F., Doğanay, Z. ve A. Fikret. (2016). Kıbrıs Türk Halkının Varoluş Savaşı ve Rauf R. Denktaş. Ankara: Kıbrıs Türk Kültür Derneği Genel Merkezi Yay.

Denktaş, R. (1996). Rauf Denktaş'ın Hatıraları 1964-1974. Cilt I. İstanbul: Boğaziçi Yay.

Denktaş, R. (1997). Rauf Denktaş’ın Hatıraları 1965, Cilt II. İstanbul: Boğaziçi Yay.

Denktaş, R. (2004). Kıbrıs Girit Olmasın, İstanbul: Remzi Kitapevi.

Denktaş, R. (2005). Karkot Deresi Anılar. İstanbul: Remzi Kitapevi.

Denktaş, R .(2000). Hatıralar, Toplayış, C X, İstanbul: Boğaziçi Yay.

Denktaş, R. (2007). Son Çağrı, İstanbul: Remzi Kitapevi.

Denktaş, R. (2008). Kıbrıs Elli Yıllık Hikâyesi, İstanbul: Akdeniz Haber Ajansı.

Denktaş, R. (1999). “The Crux Of The Cyprus Problem”, Perceptıons Journal Of Internatıonal Affairs:1.

Erol, H. (2014). “Kıbrıs Politikalarında Lider Rauf Denktaş'ın Rolü”. Doktora Tezi. İstanbul: Marmara Üniversitesi.

Gazioğlu, A .(1996). Ingiliz Yönetiminde Kıbrıs 2 (Enosis Çemberinde Türkler), İstanbul: Kıbrıs Araştırma ve Yayın Merkezi.

Gazioğlu, A .(2002 ). “Rum Mezalimi ve KKTC’ye Doğru”, Türkler C 19. Ankara: Yeni Türkiye Yayınları.1546.

İsmail, S. (1998). 150 Soruda Kıbrıs Sorunu, İstanbul: Kastaş Yay.

Özter, L. (2004) Ulusal Mücadelede Denktaş, Ankara: Özyurt Matbaacılık.

YALÇIN, E.(2019). “Rauf R. Denktaş'ın Kıbrıs'ta Bitmeyen Mücadelesi”. A ̈Ü. Atatürk Dergisi $4: 113$.

https://kktcb.org/tr/cumhurbaskanligi/cumhurbaskanlari/rauf-raif-denktas.(Erişim Tarihi:03.04.2020)

https://www.timeturk.com/rauf-denktas/biyografi-811815.(Erişim Tarihi:15 Mart 2020)

\section{Süreli Yayınlar}

AKIN

BOZKURT

CUMHURIYET

HÜRRIYET

GÜNEŞ

KIBRIS

MILLIYYT 